\title{
NOTES
}

\section{A SIMPLE DIFFRACTOMETER HEATING-COOLING STAGE: APPLICATION TO THE STUDY OF AN ORGANO-CLAY COMPLEX}

\author{
Key Words - Chlordimeform, Instrumentation, Organo-clay, Pesticide, Vermiculite, \\ $\mathrm{X}$-ray powder diffraction.
}

The study of the intercalation of organic compounds into clays, as in the preparation of pillared clays, is of great importance both from the theoretical point of view and for its applications in pharmacy, agriculture, clay characterization, catalysis, etc. (MacEwan and Wilson, 1980; Theng, 1974; Pinnavaia, 1983). At different temperatures, intercalated organic molecules, especially long-chain molecules, can undergo reversible phase transitions, and hydratable cations can hydrate to different degrees. These phenomena can be followed by studying the variation in $\mathrm{X}$-ray powder diffraction (XRD) basal spacing with temperature (Brindley and Ray, 1964; Lagaly and Weiss, 1971; Pfirrmann et al., 1973).

Although various temperature-control stages for powder X-ray diffractometers have been described in the literature (Brown et al., 1972; Lagaly et al., 1975; Morandi et al., 1976-1977), the advantage of the system described here is that XRD patterns can be obtained more simply and quickly for temperature ranges both below and above ambient room temperature and with greater temperature stability, due to the simultaneous use of cold and heat sources.

\section{Design and description of the stage}

The heating and cooling stage is constructed for a Philips diffractometer and consists essentially of three fundamental parts (Figure 1): the stage itself, the heating resistance, and the cold source. These three parts are independent and only need to be coupled at the moment of carrying out the XRD examination.

The stage (1) is made of anodized aluminum and is thicker than the standard Philips sample holder to permit the housing of a platinum resistance thermometer probe (5) and a thermistor (6). The stage has a groove in the form of an $\mathrm{H} \mathrm{(2),} \mathrm{which} \mathrm{acts} \mathrm{as} \mathrm{a} \mathrm{thermal} \mathrm{seal,}$ preventing heat losses from the sample cup (3) towards the sides and the axis of the diffractometer. The stage is therefore thermally isolated and mechanically bound to the system. The high diffusivity of aluminum guarantees a temperature homogeneity in the sample. The notches (4) serve as housing for the metal edging (7), which, with the screw (8), holds the assembly together. These notches are sufficiently deep that the edging does not protrude into the optical path of the X-ray beam.

The heat source (9) consists of a block of anodized aluminum of the same lateral dimensions as the sample cup, so as to avoid creating large temperature gradients. Its interior houses a Kantal resistance wire (11) in small grooves, as described by Jimenez et al. (1984). This resistance wire is supplied through a regulator governed by the thermistor (6).

The cold source (10) is made from a small brass box and has the same lateral dimensions as the sample cup. As with the heat source, it is designed to avoid creating thermal gradients. This box has a small tube in each side to permit the flow- and temperature-regulated circulation of water or whatever other liquid is used.

The use of the cold source together with the heat source is a fundamental difference of this stage to others described in the literature. The combination of both permits a very accurate regulation of the system (as the platinum resistance thermometer does not show variations greater than $\pm 0.1^{\circ} \mathrm{C}$ ). This system allows the temperature to be increased rapidly without the problem of thermal inertia, because the cold source dissipates the heat quickly. An additional advantage of this system is that the sample can cool to the required temperature rapidly, without having to change the stage.

For studies requiring a sample temperature less than that of the laboratory, a liquid at the required temperature can be circulated through the cold source; the heating resistance is then used for fine regulation of temperature.

\section{Applications of the stage to the study of a pesticide vermiculite complex}

To illustrate the application of this system, the interaction of vermiculite from Santa Olalla, Spain, with the cationic pesticide chlordimeform (Hermosin and Pérez-Rodriguez, 1981; Morillo et al., 1983) was studied. The vermiculite was saturated with sodium so that the pesticide entered the interlamellar positions. Because the spacings of the hydrated sodium vermiculite 

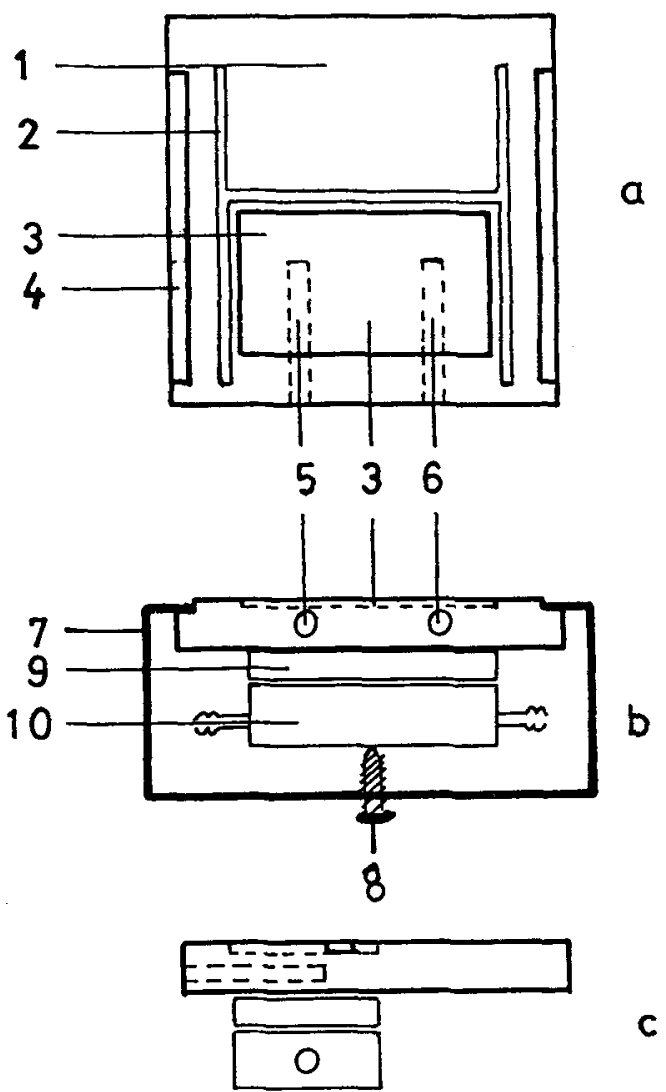

11
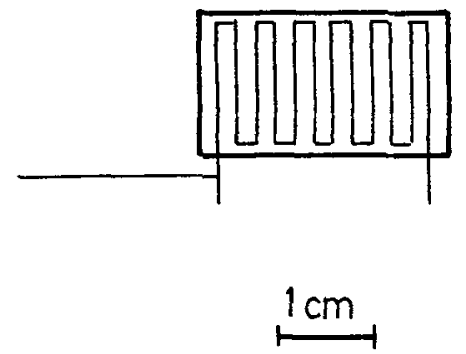

Figure 1. Scheme of the heating-cooling stage: (a) upper view; (b) frontal view; (c) side view; (d) upper view, heat source.

and the chlordimeform-vermiculite complex are very similar (14.9 and $14.7 \AA$, respectively), it is difficult to be sure that the pesticide actually entered interlamellar positions.

On heating the $\mathrm{Na}$-vermiculite to $110^{\circ} \mathrm{C}$, the basal spacing should decrease to $12.6 \AA$ (Morillo, 1988), hence, the persistence of the spacing at $14 \AA$ suggests that the pesticide had entered the interlamellar positions. Most of the samples, however, could not be heated to even moderately high temperatures, because the organic compound volatilized or decomposed. On the other hand, if the sample was removed from the oven and examined at relatively high humidity, the Na-vermiculite rehydrated rapidly, giving a characteristic
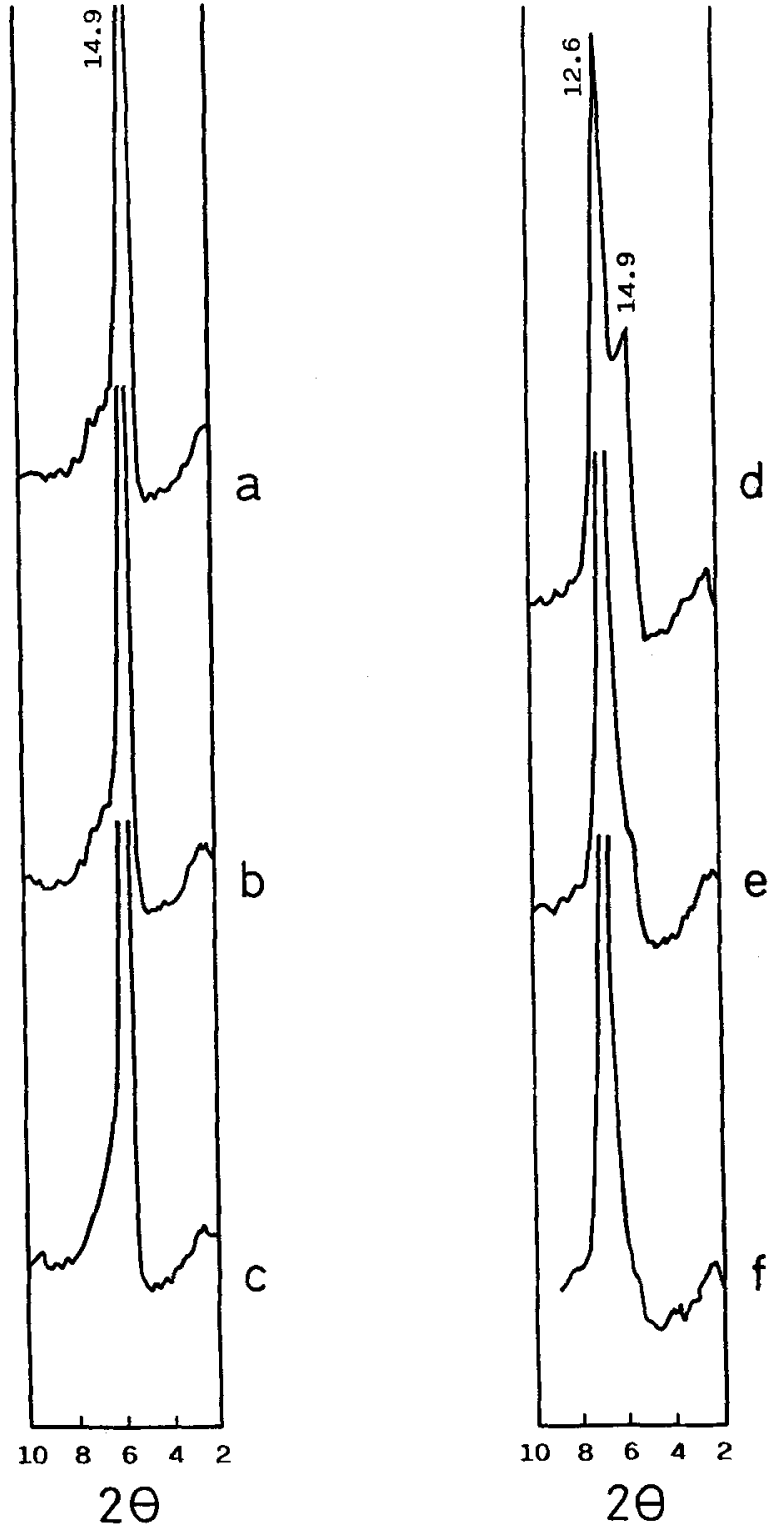

Figure 2. X-ray powder diffraction patterns $(\mathrm{CuK} \alpha$ radiation) of Na-vermiculite: (a) $7^{\circ} \mathrm{C}$; (b) $15^{\circ} \mathrm{C}$; (c) $19^{\circ} \mathrm{C}$; (d) $20^{\circ} \mathrm{C}$; (e) $20^{\circ} \mathrm{C}$ (after $10 \mathrm{~min}$ ); (f) $22^{\circ} \mathrm{C}$.

spacing at $14.9 \AA$, which overlapped with that of the vermiculite-chlordimeform complex.

To resolve this problem, the Na-vermiculite was subjected to heating-cooling cycles between $15^{\circ}$ and $25^{\circ} \mathrm{C}$, measuring the diffractions at $1^{\circ} \mathrm{C}$ steps. The 14.9-Â basal spacing remained constant to $20^{\circ} \mathrm{C}$, above which the $12.6-\AA$ line appeared, in addition to the 14.9-Å line. The 12.6- $\AA$ line increased in intensity with time, and after $10 \mathrm{~min}$ it was the only diffraction line remaining in the angular interval studied. If the sample was examined at $21^{\circ} \mathrm{C}$, the $12.6-\AA$ phase formed practically instantaneously, being the stable phase from this temperature in the range of temperatures studied. 


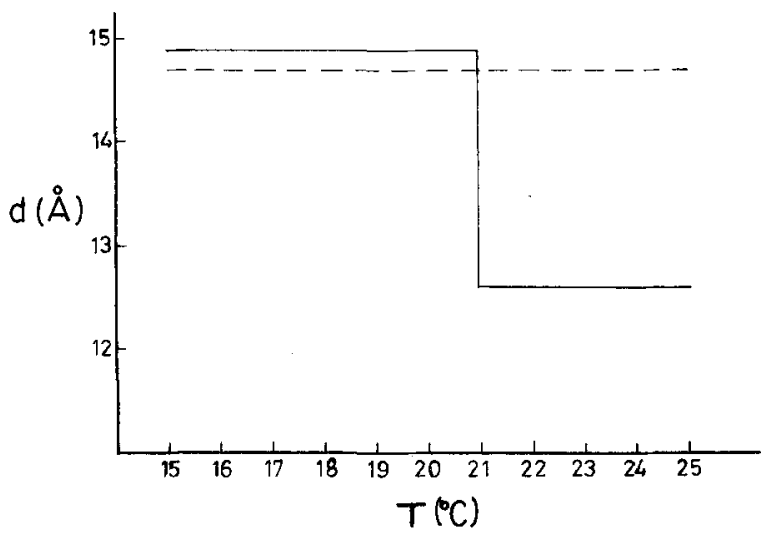

Figure 3. Variation of basal spacing $d(001)$ as function of temperature of Na-vermiculite $(-)$ and vermiculite-chlordimeform (-- ).

If the $12.6-\AA$ phase was examined at progressively decreasing temperatures at relatively high humidity, the reflection at $14.9 \AA$ began to appear at $20^{\circ} \mathrm{C}$. The 14.9- $\AA$ phase was the only phase present if the sample was examined at $19^{\circ} \mathrm{C}$ or less. The heating-cooling cycles were totally reversible.

Subjecting the chlordimeform-vermiculite complex to an analogous heating cycle, the basal spacing of 14.7 $\AA$ did not vary between $7^{\circ}$ and $35^{\circ} \mathrm{C}$. At which $35^{\circ} \mathrm{C}$, the spacing begins to vary due to the slow decomposition of the pesticide (Figure 3).

Using this type of stage, the presence of organic species in interlamellar positions of swellable clay minerals can be investigated, even in the presence of inorganic cations of high hydration energy, which give spacings in the same $2 \theta$ range as those of the compounds studied.

Instituto de Ciencia de Materiales

C.S.I.C., Apdo. 1052

41080 Sevilla, Spain

Instituto de Recursos

Naturales y Agrobiologia

C.S.I.C., Apdo. 1052

41080 Sevilla, Spain

ESMERALDA MORILLO Celia Maqueda
ANGEL JUSTO

Departamento de Termologia

JUSTO JIMENEZ Universidad de Sevilla

Sevilla, Spain

\section{REFERENCES}

Brindley, G. W. and Ray, S. (1964) Complex of Ca-montmorillonite with primary monohydric alcohols (Clay-organic studies-VIII): Amer. Miner. 49, 106-115.

Brown, G., Edwards, B., Ormerod, E. C., and Weir, A. H. (1972) A simple diffractometer heating stage: Clay Miner. 9, 407-413.

Hermosín, M. C. and Pérez Rodríguez, J. L. (1981) Interaction of chlordimeform with clay minerals. Clays \& Clay Minerals 29, 143-152.

Jimenez, J., Rojas, E., and Zamora, M. (1984) Design and construction of precision heat fluxmeters: J. Appl. Phys. $\mathbf{5 6}$, 3353-3356.

Lagaly, G., Fitz, St., and Weiss, A. (1975) Kink block structures in clay organic complexes: Clays \& Clay Minerals 23 , $45-54$.

Lagaly, G. and Weiss, A. (1971) Experimental evidence for kink formation: Angew. Chemie Int. Edit. 10, 558-559.

MacEwan, D. M. and Wilson, M. J. (1980) Interlayer and intercalation complexes of clay minerals: in Crystal Structures of Clay Minerals and their X-ray Identification, G, W. Brindley and G. Brown, eds., Mineralogical Society, London, 197-248.

Morandi, N., Poppi, L., and Grassi, G. (1976-1977) Semplice apparato riscaldante per la tecnica diffractometrica di preparati orientati di argille: Miner. Petrogr. Acta 21, 145148.

Morillo, E. (1988) Interacción de varios plaguicidas con montmorillonita y vermiculita y sus complejos de decilamonio y con ácidos húmicos y fúlvicos: Thesis. University of Sevilla, Sevilla, Spain, 263 pp.

Morillo, E., Pérez-Rodríguez, J. L., and Hermosín, M. C. (1983) Estudio del complejo interlaminar vermiculitaclordimeform: Bol. Soc. Esp. Mineral. 7, 25-30.

Pfirrmann, G., Lagaly, G., and Weiss, A. (1973) Phase transitions in complexes of nontronite with n-alkanols: Clays \& Clay Minerals 21, 239-247.

Pinnavaia, T. J. (1983) Intercalated clay catalysts: Science 220, 365-371.

Theng, B. K. G. (1974) in The Chemistry of Clay-Organic Reactions: Adam Hilger, London, 343 pp.
(Received 22 April 1989; accepted 15 August 1990; Ms. 1907) 